\title{
KEBIASAAN MEROKOK ORANG TUA DENGAN KEJADIAN PNEUMONIA PADA BALITA
}

\author{
Putu Susy Natha Astini ${ }^{1}$, Roni Andrian Gupta ${ }^{2}$, NLP. Yunianti Suntari ${ }^{3}$, \\ IDAK Surinati ${ }^{4}$ \\ 1,2,3 Jurusan Keperawatan Politeknik Kesehatan \\ Denpasar, Bali, Indonesia
}

\begin{abstract}
Email: yuni.suntari@yahoo.com ${ }^{1}$ (correspondensi), susynathaastini@ gmail.com, ronnygupta95@gmail.com
\end{abstract}

\begin{abstract}
Parenting Smoking Habits To The Incidence Of Pneumonia Children In Wangaya Hospital 2019. Pneumonia is a disease caused by bacteria pneumococcus, staphylococcus, streptococcus, and viruses. The causes of pneumonia are divided into intrinsic factors and extrinsic factors. The type of research used in this study was nonexperimental research with a type of correlational research and cross sectional approach using non probability sampling with purposive sampling. The number of samples is 56 toddlers. This research was conducted in April to May 2019. Data collection using a questionnaire. The results showed that parents with the most smoking habits aged 30 years, with male sex (80.4\%), work for self-employed / service traders (35.8\%), high school education / SMK (50\%), current smoking status (62.5\%), no smoking (37.5\%), duration of smoking <10 years (44.6\%), and active smokers $(62.5 \%)$. Hypothesis testing uses the chi square test and multiple logistic regression with $p$ values of 0.024 each and the most related variable is the type of smoker with an OR value of 19.00.
\end{abstract}

Key words: Toddler:Peneumonia:Smoking Habit

Abstrak :Kebiasaan Merokok Orang Tua Dengan Kejadian Pneumonia Pada Balita Di Rsud Wangaya. Pneumonia adalah penyakit yang disebabkan kuman pneumococcus, staphylococcus, streptococcus, dan virus. Faktor ekstrinsik meliputi kepadatan tempat tinggal, polusi udara, tipe rumah, ventilasi, dan kebiasaan merokok orang tua. Jenis penelitian yang digunakan dalam penelitian ini adalah penelitian noneksperimen dengan jenis penelitian korelasional dan pendekatan cross sectional menggunakan non probability sampling dengan purposive sampling. Jumlah sampel sebanyak 56 balita. Penelitian ini dilakukan pada bulan april sampai mei 2019. pengumpulan data menggunakan kuesioner. Hasil penelitian menunjukkan orang tua dengan kebiasaan merokok terbanyak usia 30 tahun, dengan jenis kelamin laki - laki $(80,4 \%)$, pekerjaan wiraswasta/pedagang jasa $(35,8 \%)$, pendidikan sma/smk $(50 \%)$, status merokok saat ini $(62,5 \%)$, tidak merokok $(37,5 \%)$, lamanya merokok <10 tahun $(44,6 \%)$, dan perokok aktif $(62,5 \%)$. uji hipotesis menggunakan uji chi square dan regresi logistik ganda dengan nilai p masing-masing 0,024 dan variabel yang paling berhubungan yaitu jenis perokok dengan nilai or yaitu 19,00 .

Kata kunci : Balita; Pneumonia; Kebiasaan merokok 
Putu Susy Natha Astini, Roni Andrian Gupta, NLP. Yunianti Suntari, IDAK Surinati. Desember 2020. 13 (2). 77-86

\section{PENDAHULUAN}

Salah satu penyebab kematian tertinggi akibat penyakit infeksi pada balita adalah pneumonia. Pneumonia adalah penyakit yang disebabkan kuman pneumococcus, staphylococcus, streptococcus, dan virus. Gejala penyakit pneumonia yaitu menggigil, demam, sakit kepala, batuk, mengeluarkan dahak, dan sesak napas. (1)

Hasil Riskesdas tahun 20152017, menyebutkan bahwa pneumonia menduduki peringkat kedua sebagai penyebab kematian pada balita sebesar $15,5 \%$. Selama tiga tahun terakhir prevalensi pneumonia pada balita di Indonesia pada tahun 2015 - 2016 mengalami peningkatan yaitu sebesar $63,45 \%$ tahun 2015 dibandingkan tahun 2016 sebesar $65,27 \%$. Tahun 2016-2017 prevalensi penemuan pneumonia pada balita di Indonesia mengalami penurunan sebesar 14,08\% dibandingkan dari tahun sebelumnya yaitu 51,19\% tahun 2017. (Kementerian Kesehatan RI, 2017)

Cakupan penemuan kasus pneumonia pada balita di Provinsi Bali menempati urutan ketiga setelah diare, tahun 2016 - 2018 pneumonia pada balita mengalami peningkatan, di tahun 2016 prevalensi pneumonia pada balita sebesar $32,44 \%$ dengan jumlah kasus 2.640 balita dari 8.139 jumlah perkiraan pneumonia balita. Tahun 2017 prevalensi pneumonia pada balita lebih tinggi dari tahun 2016 sebesar 45,03\% dengan jumlah kasus 3.764 balita dari 8.359 jumlah perkiraan pneumonia balita. Prevalensi pada tahun 2018 meningkat dari tahun 2016-2017 yaitu sebesar $58,35 \%$ dengan jumlah kasus 4.777 balita dari 8.187 jumlah perkiraan pneumonia balita. Tingkat kabupaten/kota pada tahun 2018 penemuan tertinggi kasus pneumonia adalah Kabupaten Karangsem yaitu 92,67\% dengan jumlah kasus 788 balita dari 850 jumlah pneumonia balita. Kabupaten Denpasar dengan penemuan kasus pneumonia pada balita sebesar $58,55 \%$ dengan jumlah kasus 1.117 balita dari 1.908 jumlah pneumonia balita. (Dinas Kesehatan Provinsi Bali, 2018)

Penemuan pneumonia pada balita di Kota Denpasar mengalami peningkatan dari tahun 2016 - 2018 . Tahun 2016 prevalensi pneumonia pada balita sebesar $44,68 \%$ dengan jumlah kasus 668 balita dari perkiraan 1.495 jumlah pneumonia balita. Tahun 2017 prevalensi pneumonia balita sebesar $54,31 \%$ dengan jumlah kasus 1.018 balita dari perkiraan 1.874 jumlah pneumonia balita, sedangkan di tahun 2018 prevalensi pneumonia balita sebesar 58,55\% dengan jumlah kasus 1.117 balita dari 1.908 jumlah pneumonia balita (3). Menurut catatan rekam medik pasien di RSUD Wangaya pneumonia menjadi salah satu dari penyakit 10 besar mematikan setiap tahunnya. Data pneumonia balita di RSUD Wangaya pada tahun 2017 2018 mengalami peningkatan yang tidak terlalu signifikan. Pada tahun 2017 terdapat 258 kasus pneumonia pada balita, sedangkan pada tahun 2018 penemuan pneumonia pada balita sebanyak 297 kasus (RSUD Wangaya, 2018)

Penyebab pneumonia terbagi atas faktor instrinsik dan faktor ekstrinsik. Faktor instrinsik meliputi umur, jenis kelamin, status gizi, Berat Badan Lahir Rendah (BBLR), status imunisasi, pemberian Air Susu Ibu (ASI), dan pemberian vitamin A. Faktor ekstrinsik meliputi kepadatan tempat 
Putu Susy Natha Astini, Roni Andrian Gupta, NLP. Yunianti Suntari, IDAK Surinati.

Desember 2020. 13 (2). 77-86

tinggal, polusi udara, tipe rumah, ventilasi, dan asap rokok (4).

Kebiasaan anggota keluarga merokok di dalam rumah merupakan masalah yang mengkhawatirkan di Indonesia. Keberadaan anggota keluarga yang merokok di dalam rumah menjadi faktor penyebab terjadinya masalah kesehatan di dalam keluarga seperti gangguan pernafasan dan dapat meningkatkan serangan ISPA khususnya pada balita. Anak-anak yang orang tuanya merokok lebih rentan terkena penyakit pernafasan seperti flu, asma, pneumonia dan penyakit saluran pernafasan lainnya (Kusuma, 2015)

Rata- rata proporsi perokok menurut Riskesdas tahun 2013 di Indonesia adalah 29,3 persen. Proporsi terbanyak perokok aktif setiap hari pada umur 30-34 tahun sebesar 33,4 persen, umur 35-39 tahun sebesar 32,2 persen, sedangkan proporsi perokok setiap hari pada laki-laki lebih banyak dibandingkan perokok perempuan yaitu 47,5 persen banding 1,1 persen. (6)

Hasil prevalensi kebiasaan merokok setiap hari di Dinas Kesehatan Provinsi Bali sebanyak 18,0\% di usia $\geq$ 10 tahun dengan jumlah batang rokok (kretek, putih, dan linting) yang dihisap setiap hari sebesar $12,0 \%$. Dari angka tersebut, kebiasaan merokok pria lebih besar dibandingkan dengan perempuan yaitu $35,2 \%$, sedangkan perempuan sebanyak $0,6 \%$ berdasarkan kebiasaan merokok setiap harinya. Data tertinggi kebiasaan merokok di Pronvinsi Bali terdapat di Kabupaten Jembrana dengan jumlah 22,8\%, sedangkan yang terendah terdapat di Kabupaten Gianyar dengan jumlah 11,0\%. Prevalensi kebiasaan merokok di Kota Denpasar sebesar $17,5 \%$.(7)

Penelitian yang dilakukan oleh Kusuma, Winarsih \& Sukini (2015) menunjukkan ada hubungan antara paparan asap rokok dengan kejadian
ISPA pada Balita di Desa Pucungrejo Magelang. Dari 42 responden yang diteliti 2 balita menderita pneumonia berat yang mendapat paparan asap rokok, 3 balita menderita pneumonia yang mendapat paparan asap rokok, dan sisanya merupakan kejadian tidak ISPA yang sebagian besar terjadi pada balita yang tidak mendapatkan paparan asap rokok. (5)

Upaya pemerintah dalam menekan angka kematian akibat pneumonia diantaranya melalui penemuan kasus pneumonia balita sedini mungkin di pelayanan kesehatan dasar, penatalaksanaan kasus dan rujukan. Adanya keterpaduan dengan lintas program melalui pendekatan MTBS di daerah terpencil (8). Dalam mengingatkan masyarakat untuk menjaga kesehatan, upaya yang dilakukan Kementerian Kesehatan RI mewujudkan Indonesia sehat melalui Gerakan Masyarakat Hidup Sehat (GERMAS). GERMAS dilakukan dengan cara : melakukan aktivitas fisik, mengkonsumsi sayuran dan buah, tidak merokok, tidak mengkonsumsi alcohol, memeriksa kesehatan secara rutin, membersihkan lingkungan, dan menggunakan jamban. (9).

\section{METODE}

Penelitian ini merupakan penelitian non-eksperimen dengan jenis penelitian korelasional dan menggunakan pendekatan cross sectional. Teknik pengambilan sampel non probability sampling dengan purposive sampling. Jumlah sampel 56 orang. Penelitian ini dilaksanakan pada bulan April sampai Mei 2019. Pengumpulan data menggunakan kuesioner kebiasaan merokok dengan 4 pernyataan dan penelusuran rekam medik.

Teknik analisa data yang digunakan untuk menguji hipotesis 
Putu Susy Natha Astini, Roni Andrian Gupta, NLP. Yunianti Suntari, IDAK Surinati. Desember 2020. 13 (2). 77-86

dengan menggunakan uji statistic, yaitu dengan Uji chi square untuk mengetahui hubungan physical activity dengan derajat hipertemsi dengan $\alpha=0,05$.

\section{HASIL DAN PEMBAHASAN}

Penelitian ini dilakukan di daerah Wangaya, tepatnya di RSUD Wangaya Denpasar. Subyek penelitian dalam penelitian ini yaitu orang tua balita dengan pneumonia di RSUD Wangaya sesuai kriteria inklusi dan ekslusi sebanyak 56 orang.

Tabel 1. Distribusi Karakteristik Orang Tua yang Mempunyai Balita Dengan Pneumonia Berdasarkan Usia

\begin{tabular}{cccccc}
\hline N & Mean & $\begin{array}{c}\text { Med } \\
\text { ian }\end{array}$ & $\begin{array}{c}\text { Mod } \\
\text { us }\end{array}$ & $\begin{array}{c}\text { Standa } \\
\text { Devias } \\
\text { i }\end{array}$ & $\begin{array}{c}\text { Min- } \\
\text { Max }\end{array}$ \\
\hline 5 & 35,79 & $\begin{array}{c}36,5 \\
0\end{array}$ & 30 & 5,598 & $27-47$ \\
6 & & & & \\
\hline
\end{tabular}

Hasil interpretasi tabel 1 diatas, dari 56 responden didapatkan bahwa rata-rata usia responden yaitu 35,79 tahun dengan usia terbanyak yaitu 30 tahun.

Tabel 2. Distribusi Frekuensi Karakteristik Orang Tua yang Mempunyai Balita Dengan Pneumonia Berdasarkan Jenis Kelamin

\begin{tabular}{rlrr}
\hline No & $\begin{array}{c}\text { Jenis } \\
\text { Kelami } \\
\text { n }\end{array}$ & $\begin{array}{c}\text { Frek } \\
\text { uensi } \\
\text { (n) }\end{array}$ & \multicolumn{1}{c}{$\begin{array}{c}\text { Persenta } \\
\text { se }(\%)\end{array}$} \\
\hline 1 & $\begin{array}{l}\text { Laki- } \\
\text { laki }\end{array}$ & 45 & 80,4 \\
2 & $\begin{array}{l}\text { Peremp } \\
\text { uan }\end{array}$ & 11 & 19,6 \\
\hline & Jumlah & 56 & 100 \\
\hline
\end{tabular}

Dilihat dari tabel 2 diatas, 56 responden didapatkan bahwa $80,4 \%$ berjenis kelamin laki-laki dan 19,6\% berjenis kelamin perempuan.
Tabel 3. Distribusi Frekuensi Karakteristik Orang Tua yang Mempunyai Balita Dengan Pneumonia Berdasarkan Pekerjan

\begin{tabular}{rlrr}
\hline No & Pekerjaan & $\begin{array}{c}\text { Frek } \\
\text { uensi } \\
(\mathbf{n})\end{array}$ & $\begin{array}{r}\text { Persentas } \\
\text { e }(\%)\end{array}$ \\
\hline 1 & $\begin{array}{l}\text { Tidak } \\
\text { bekerja }\end{array}$ & 4 & 7,1 \\
2 & $\begin{array}{l}\text { PNS/TNI/Po } \\
\text { lri/ }\end{array}$ & & \\
& BUMN/BU & 3 & 5,4 \\
& MD \\
3 & Pegawai & & \\
& swasta & 4 & 7,1 \\
4 & Wiraswasta/ & & \\
& Pedagang/Ja & 20 & 35,8 \\
& sa & & \\
5 & Petani & 14 & 25,0 \\
6 & Buruh & 11 & 19,6 \\
\hline & Jumlah & 56 & 100 \\
\hline
\end{tabular}

Dilihat dari distribusi frekuensi pekerjaan orang tua dari 56 responden didapatkan yaitu $35,8 \%$ bekerja sebagai wiraswasta/pedagang/jasa

Tabel 4. Distribusi Frekuensi Karakteristik Orang Tua Balita Pneumonia. Berdasarkan Pendidikan

\begin{tabular}{clrr}
\hline $\begin{array}{c}\text { N } \\
\text { o }\end{array}$ & Pendidikan & $\begin{array}{c}\text { Frekue } \\
\text { nsi (n) }\end{array}$ & $\begin{array}{c}\text { Persentase } \\
(\%)\end{array}$ \\
\hline 1 & SD & 4 & 7,1 \\
2 & SMP & 20 & 35,8 \\
3 & SMA/SMK & 28 & 50,0 \\
4 & Perguruan & 4 & 7,1 \\
& Tinggi & & 100 \\
\hline & Jumlah & 56 & \\
\hline
\end{tabular}

Pendidikan orang tua dari 56 responden didapatkan bahwa 50\% berpendidikan terakhir SMA/SMK. 
Putu Susy Natha Astini, Roni Andrian Gupta, NLP. Yunianti Suntari, IDAK Surinati. Desember 2020. 13 (2). 77-86

Tabel 5. Distribusi Frekuensi Kebiasaan Merokok Orang Tua yang Mempunyai Balita Dengan Pneumonia Berdasarkan Status Merokok.

\begin{tabular}{|c|c|c|c|}
\hline $\begin{array}{l}\mathbf{N} \\
\mathbf{o}\end{array}$ & $\begin{array}{c}\text { Status } \\
\text { Merokok }\end{array}$ & $\begin{array}{l}\text { Fre } \\
\text { kue } \\
\text { nsi } \\
(n)\end{array}$ & $\begin{array}{c}\text { Persentase } \\
(\%)\end{array}$ \\
\hline 1 & $\begin{array}{l}\text { Merokok } \\
\text { saat ini }\end{array}$ & 35 & 62,5 \\
\hline 2 & $\begin{array}{l}\text { Mantan } \\
\text { perokok }\end{array}$ & 11 & 19,6 \\
\hline 3 & $\begin{array}{l}\text { Tidak } \\
\text { pernah } \\
\text { merokok }\end{array}$ & 10 & 17,9 \\
\hline & Jumlah & 56 & 100 \\
\hline
\end{tabular}

Kebiasaan merokok orang tua dari 56 responden berdasarkan status merokok didapatkan bahwa $62,5 \%$ memiliki status merokok saat ini.

Tabel 6. Distribusi Frekuensi Kebiasaan Merokok Orang Tua yang Mempunyai Balita Dengan Pneumonia Berdasarkan Jumlah Batang Rokok Yang Dikonsumsi.

\begin{tabular}{clrr}
\hline $\begin{array}{c}\text { N } \\
\text { o }\end{array}$ & $\begin{array}{c}\text { Jumlah Batang } \\
\text { Rokok }\end{array}$ & $\begin{array}{c}\text { Frek } \\
\text { uensi } \\
\text { (n) }\end{array}$ & $\begin{array}{c}\text { Persenta } \\
\text { se (\%) }\end{array}$ \\
\hline 1 & $>31$ batang/hari & 3 & 5,4 \\
2 & $\begin{array}{l}21-31 \\
\text { batang/hari }\end{array}$ & 10 & 17,9 \\
3 & $\begin{array}{l}11-20 \\
\text { batang/hari }\end{array}$ & 18 & 32,1 \\
4 & $\leq 10$ batang/hari & 4 & 7,1 \\
5 & Tidak merokok & 21 & 37,5 \\
\hline & Jumlah & 56 & 100 \\
\hline
\end{tabular}

Distribusi frekuensi kebiasaan merokok orang tua berdasarkan jumlah batang rokok yang dikonsumsi dari 56 responden didapatkan yaitu $37,5 \%$ tidak merokok.
Tabel 7.. Distribusi Frekuensi Kebiasaan Merokok Orang Tua yang Mempunyai Balita Dengan Pneumonia Berdasarkan Lamanya Merokok.

\begin{tabular}{|c|c|c|c|}
\hline $\mathbf{N}$ & $\begin{array}{c}\text { Lama } \\
\text { Meokok }\end{array}$ & $\begin{array}{c}\text { Frek } \\
\text { uensi } \\
\text { (n) }\end{array}$ & $\begin{array}{c}\text { Persentase } \\
(\%)\end{array}$ \\
\hline 1 & $>20$ tahun & 3 & 5,4 \\
\hline 2 & 10-20 tahun & 7 & 12,5 \\
\hline 3 & $<10$ tahun & 25 & 44,6 \\
\hline 4 & Tidak merokok & 21 & 37,5 \\
\hline & Jumlah & 56 & 100 \\
\hline
\end{tabular}

Dilihat dari tabel 7 diatas, dari 56 responden didapatkan bahwa 44,6\% sudah merokok selama $<10$ tahun, Tabel 8. Distribusi Frekuensi Kebiasaan Merokok Orang Tua yang Mempunyai Balita Dengan Pneumonia Berdasarkan Jenis Perokok.

\begin{tabular}{|c|c|c|c|}
\hline $\mathbf{N}$ & $\begin{array}{c}\text { Jenis } \\
\text { Perokok }\end{array}$ & $\begin{array}{c}\text { Frekue } \\
\text { nsi (n) }\end{array}$ & $\begin{array}{c}\text { Persentas } \\
\text { e }(\%)\end{array}$ \\
\hline 1 & Aktif & 35 & 62,5 \\
\hline 2 & Pasif & 21 & 27,5 \\
\hline & Jumlah & 56 & 100 \\
\hline
\end{tabular}

Kebiasaan merokok orang tua berdasarkan jenis perokok dari 56 responden didapatkan bahwa $62,5 \%$ sebagai perokok aktif.

Tabel 9. Distribusi Frekuensi Orang Tua yang Mempunyai Balita dengan Pneumonia Berdasarkan Kejadian Pneumonia

\begin{tabular}{clcc}
\hline $\begin{array}{c}\text { N } \\
\text { o }\end{array}$ & $\begin{array}{c}\text { Kejadian } \\
\text { Pneumonia }\end{array}$ & $\begin{array}{c}\text { Frek } \\
\text { uensi } \\
(\mathbf{n})\end{array}$ & $\begin{array}{c}\text { Persen } \\
\text { tase } \\
(\%)\end{array}$ \\
\hline 1 & $\begin{array}{l}\text { Pneumonia } \\
\text { berat }\end{array}$ & 15 & 26,8 \\
2 & Pneumonia & 41 & 73,2 \\
\hline & Jumlah & 56 & 100 \\
\hline
\end{tabular}

Berdasarkan distribusi frekuensi orang tua yang mempunyai balita dengan pneumonia dari 56 responden didapatkan bahwa $73,2 \%$ mengalami pneumonia. $26,8 \%$ mengalami pneumonia berat. 
Putu Susy Natha Astini, Roni Andrian Gupta, NLP. Yunianti Suntari, IDAK Surinati. Desember 2020. 13 (2). 77-86

Tabel 10. Analisis Bivariat Hubungan Status Merokok Orang Tua Dengan Kejadian Pneumonia Pada Balita.

\begin{tabular}{|c|c|c|c|c|c|c|c|c|}
\hline \multirow{3}{*}{$\begin{array}{c}\text { Status } \\
\text { Merokok }\end{array}$} & \multicolumn{4}{|c|}{ Kejadian Pneumonia } & & & \multirow[t]{3}{*}{$\mathrm{P}$} & \multirow{3}{*}{$\begin{array}{c}\text { OR } \\
(95 \% \mathrm{CI})\end{array}$} \\
\hline & \multicolumn{2}{|c|}{$\begin{array}{c}\text { Pneumonia } \\
\text { Berat }\end{array}$} & \multicolumn{2}{|c|}{$\begin{array}{c}\text { Pneumoni } \\
\text { a }\end{array}$} & \multicolumn{2}{|c|}{ Jumlah } & & \\
\hline & $\mathbf{F}$ & $\%$ & f & $\%$ & $\mathbf{f}$ & $\%$ & & \\
\hline $\begin{array}{l}\text { Merokok } \\
\text { saat ini }\end{array}$ & 13 & 23,2 & 22 & $\begin{array}{r}39, \\
3\end{array}$ & 35 & 62,5 & & $\begin{array}{c}5,318 \\
(0,603- \\
46,895)\end{array}$ \\
\hline $\begin{array}{l}\text { Mantan } \\
\text { perokok }\end{array}$ & 1 & 1,8 & 10 & $\begin{array}{r}17, \\
8\end{array}$ & 11 & 19,6 & 0,024 & $\begin{array}{c}0,900 \\
(0,049- \\
12,691)\end{array}$ \\
\hline $\begin{array}{l}\text { Tidak } \\
\text { pernah } \\
\text { merokok }\end{array}$ & 1 & 1,8 & 9 & $\begin{array}{r}16, \\
1\end{array}$ & 10 & 17,9 & & Pembanding \\
\hline Jumlah & 15 & 26,8 & 41 & $\begin{array}{r}73, \\
2\end{array}$ & 56 & 100 & & \\
\hline
\end{tabular}

Dilihat dari analisis bivariat hubungan status merokok dengan kejadian pneumonia, didapatkan bahwa hasil terbanyak yaitu orang tua dengan status merokok saat ini memiliki balita dengan pneumonia dengan persentase $39,3 \%$, orang tua dengan status mantan perokok terbanyak memiliki balita dengan pneumonia dengan persentase $17,8 \%$, sedangkan orang tua dengan status tidak pernah merokok terbanyak

Tabel 11. Analisis Bivariat Hubungan Jumlah Batang Rokok Yang Dihisap Orang Tua Dengan Kejadian Pneumonia

\begin{tabular}{|c|c|c|c|c|c|c|c|c|c|}
\hline \multirow{3}{*}{$\begin{array}{l}\text { Jumlah } \\
\text { Batang } \\
\text { Rokok }\end{array}$} & \multicolumn{5}{|c|}{ Kejadian Pneumonia } & \multirow{2}{*}{\multicolumn{2}{|c|}{ Jumlah }} & \multirow[t]{3}{*}{$\mathrm{p}$} & \multirow{3}{*}{$\begin{array}{c}\text { OR } \\
(95 \% \mathrm{CI})\end{array}$} \\
\hline & \multicolumn{3}{|c|}{ Pneumonia Berat } & \multicolumn{2}{|c|}{ Pneumonia } & & & & \\
\hline & $\mathbf{f}$ & & $\%$ & $\mathbf{f}$ & $\%$ & $\mathbf{F}$ & $\%$ & & \\
\hline $\begin{array}{l}>31 \\
\text { batang/hari }\end{array}$ & & 2 & 3,6 & 1 & 1,8 & 3 & 5,4 & & $\begin{array}{c}19,00(1,146 \\
-314,971)\end{array}$ \\
\hline $\begin{array}{l}21-31 \\
\text { batang/hari }\end{array}$ & & 5 & 8,9 & 5 & 8,9 & 10 & 17,9 & & $\begin{array}{c}9,50(1,403- \\
64,346)\end{array}$ \\
\hline $\begin{array}{l}11-20 \\
\text { batang/hari }\end{array}$ & & 4 & 7,1 & 14 & 25,0 & 18 & 32,1 & 0,024 & $\begin{array}{c}2,714(0,434 \\
-16,961)\end{array}$ \\
\hline $\begin{array}{l}\leq 10 \\
\text { batang/hari }\end{array}$ & & 2 & 3,6 & 2 & 3,6 & 4 & 7,1 & & $\begin{array}{c}9,50(0,826- \\
109,235)\end{array}$ \\
\hline $\begin{array}{l}\text { Tidak } \\
\text { merokok }\end{array}$ & & 2 & 3,6 & 19 & 33,9 & 21 & 37,5 & & Pembanding \\
\hline Jumlah & & 15 & 26,8 & 41 & 73,2 & 56 & 100 & & \\
\hline
\end{tabular}


Putu Susy Natha Astini, Roni Andrian Gupta, NLP. Yunianti Suntari, IDAK Surinati. Desember 2020. 13 (2). 77-86

Berdasarkan analisis bivariat hubungan jumlah batang rokok yang dikonsumsi dengan kejadian pneumonia, didapatkan bahwa orang tua yang mengonsumsi >31 batang rokok/hari memiliki balita dengan pneumonia berat dengan persentase $3,6 \%$, orang tua yang mengonsumsi 21 31 batang rokok/hari memiliki balita dengan pneumonia berat dan pneumonia dengan persentase masingmasing $8,9 \%$, orang tua yang mengonsumsi 11-20 batang rokok/hari memiliki balita dengan pneumonia dengan persentase $25,0 \%$, orang tua yang mengonsumsi $\leq 10$ batang rokok/hari memiliki balita dengan

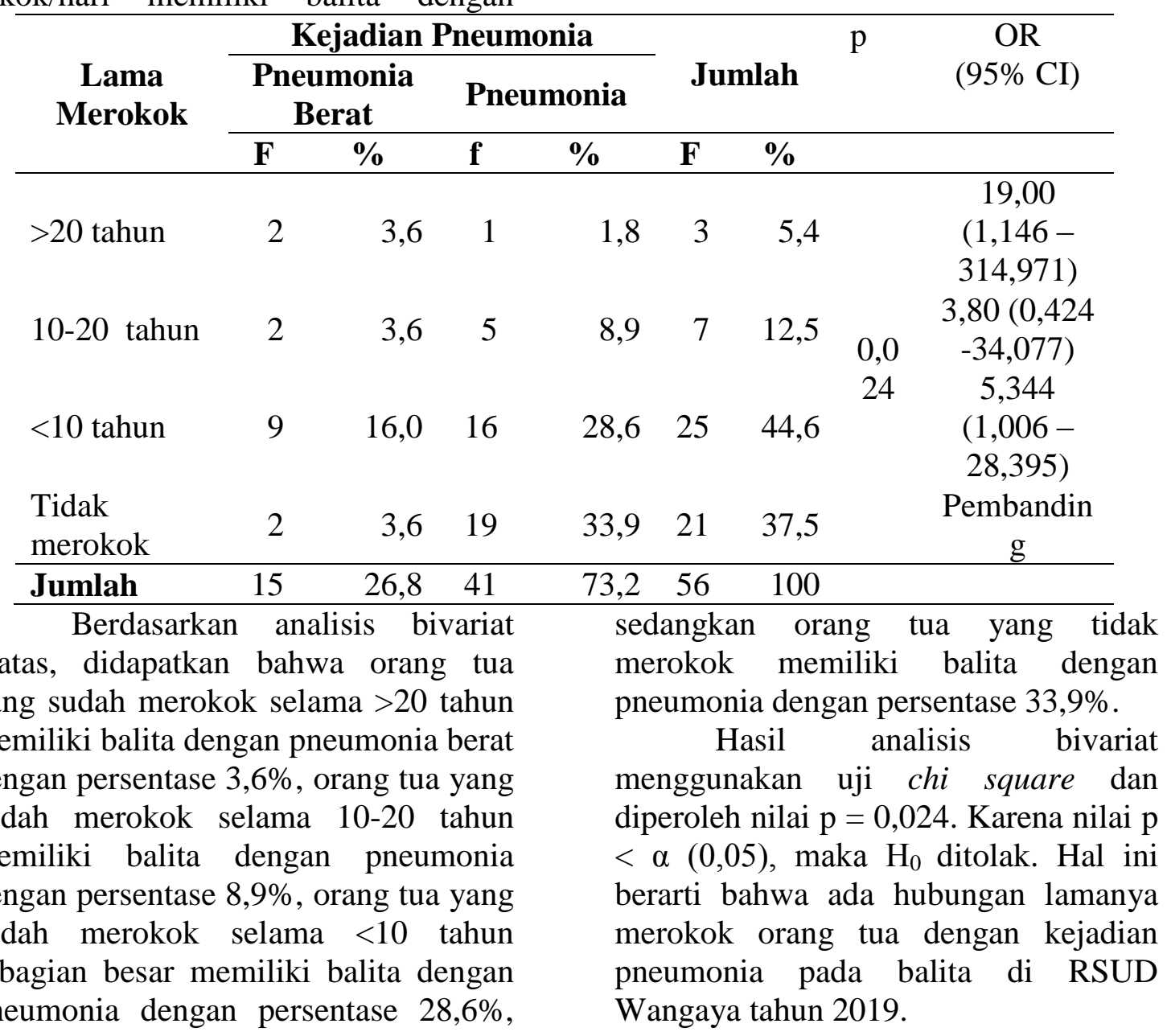

pneumonia berat dan pneumonia dengan persentase masing-masing $3,6 \%$, sedangkan orang tua yang tidak merokok memiliki balita dengan pneumonia dengan persentase $33,9 \%$, Hasil analisis bivariat menggunakan uji chi square dan diperoleh nilai $\mathrm{p}=0,024$. Karena nilai $\mathrm{p}$ $<\alpha(0,05)$, maka $\mathrm{H}_{0}$ ditolak. Hasil analisis ini berarti ada hubungan jumlah batang rokok yang dihisap orang tua dengan kejadian pneumonia pada balita di RSUD Wangaya tahun 2019. 
Putu Susy Natha Astini, Roni Andrian Gupta, NLP. Yunianti Suntari, IDAK Surinati. Desember 2020. 13 (2). 77-86

Tabel 13. Analisis Bivariat Hubungan Jenis Perokok Orang Tua Dengan Kejadian Pneumonia

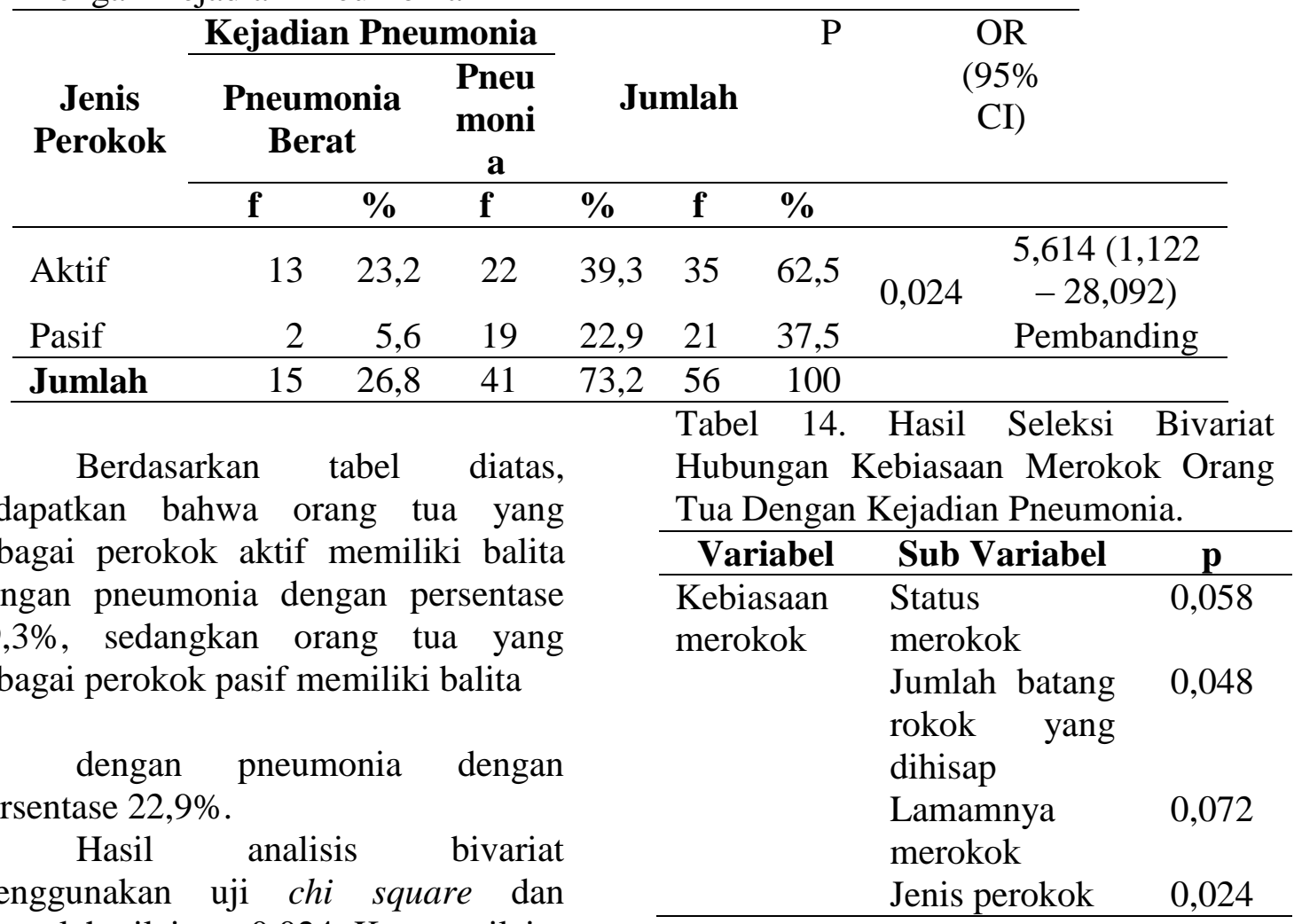

diperoleh nilai $\mathrm{p}=0,024$. Karena nilai $\mathrm{p}$ $<\alpha(0,05)$, maka $\mathrm{H}_{0}$ ditolak. Hal ini berarti bahwa ada hubungan jenis perokok dengan kejadian pneumonia pada balita di RSUD Wangaya tahun 2019.

Berdasarkan interpretasi tabel diatas, menunjukkan bahwa semua sub variabel kebiasaan merokok memiliki nilai $\mathrm{p} \leq 0,25$, hal ini berarti bahwa sub variabel status merokok, jumlah batang merokok yang dihisap, lamanya merokok, dan jenis perokok masuk ke dalam model multivariat.

Tabel 15. Analisis Multivariat Hubungan Kebiasaan Merokok Orang Tua Dengan

Kejadian Penumonia.

\begin{tabular}{lccc}
\hline & Sub Variabel & p & OR (95\% CI) \\
\hline Langkah I & Jenis perokok & 0,074 & $18,00(0,758-427,291)$ \\
& Status merokok (1) & 0,944 & $1,111(0,60-20,487)$ \\
& Jumlah batang rokok (1) & 0,681 & $1,786(0,112-28,401)$ \\
& Jumlah batang rokok (2) & 0,170 & $6,480(0,448-93,690)$ \\
& Jumlah batang rokok (3) & 0,661 & $2,00(0,090-44,350)$ \\
Langkah II & Lama merokok (1) & 0,707 & $1,460(0,203-10,500)$ \\
& Jenis perokok & 0,040 & $19,00(1,146-314,971)$ \\
& Jumlah batang rokok (1) & 0,681 & $1,786(0,112-28,401)$ \\
& Jumlah batang rokok (2) & 0,170 & $6,480(0,448-93,690)$ \\
& Jumlah batang rokok (3) & 0,661 & $2,00(0,090-44,350)$ \\
& Lama merokok (1) & 0,707 & $1,460(0,203-10,500)$ \\
\hline
\end{tabular}


Putu Susy Natha Astini, Roni Andrian Gupta, NLP. Yunianti Suntari, IDAK Surinati. Desember 2020. 13 (2). 77-86

Dilihat dari interpretasi tabel diatas, didapatkan bahwa sub variabel kebiasaan merokok yang paling berhubungan dengan kejadian pneumonia yaitu jenis perokok, sedangkan sub variabel jumlah batang rokok yang dihisap dan lama merokok sebagai variabel konfounding. Nilai OR jenis perokok yaitu $19,00 \quad(1,146-$ $314,971)$, hal ini berarti orang tua yang sebagai perokok aktif memiliki peluang 19,00 kali balitanya mengalami pneumonia berat dibandingkan dengan orang tua yang sebagai perokok pasif setelah dikontrol sub variabel jumlah batang rokok yang dihisap dan lamanya merokok.

\section{SIMPULAN}

Berdasarkan hasil penelitian dan pembahasan tentang kebiasaan merokok orang tua dengan kejadian pneumonia di RSUD Wangaya Tahun 2019 terhadap 56 responden dapat disimpulkan bahwa orang tua balita sebagian besar memiliki status merokok saat ini yaitu 62,5\%, berdasarkan jumlah batang rokok didapatkan tidak merokok yaitu $37,5 \%$, berdasarkan lamanya merokok <10 tahun yaitu $44,6 \%$, dan sebagian besar sebagai perokok aktif yaitu $62,5 \%$, kejadian pneumonia pada balita sebagian besar mengalami pneumonia yaitu $73,2 \%$, ada hubungan yang bermakna antara status merokok orang tua, jumlah batang rokok yang dihisap, lamanya merokok, dan jenis perokok orang tua dengan kejadian pneumonia pada balita di RSUD Wangaya tahun 2019 dengan nilai $\mathrm{p}$ masing-masing yaitu 0,024 , sub variabel kebiasaan merokok yang paling berhubungan dengan kejadian pneumonia pada balita di RSUD Wangaya tahun 2019 dengan nilai OR = 19,00 (95\% CI : 1,146-314,971) yaitu jenis perokok.

\section{ETIKA PENELITIAN}

Penelitian ini telah medapatkan ijin etik dari Institusi Politeknik Kesehatan Denpasar dengan nomor etik LB 02 03/EA/KEPK/0262/2019.

\section{SUMBER DANA}

Penelitian ini menggunakan

sumber dana swadana.

\section{DAFTAR RUJUKAN}

1. Kemenkes R. PROFIL KESEHATAN INDONESIA TAHUN 2013. Vol. 14, Journal of Physics A: Mathematical and General. 2014. 2171-2172 p.

2. Kementerian Kesehatan RI. HASIL UTAMA RISKESDAS 2018. 2018;

3. Dinas Kesehatan Provinsi Bali. Data Pneumonia Dinas Kesehatan Provinsi Bali. Bali; 2018.

4. Mokoginta D, Arsin A, Sidik D. Faktor resiko kejadian pneumonia pada anak balita di Wilayah kerja Puskesmas Sudiang Kota Makasar. 2013;5.

5. Kusuma N, Sri W, Sukini T. Hubungan antara paparan asap rokok dengan kejadian ISPA pada balita di Desa Pucung Rejo Kabupaten Magelang. J

Kebidanan. 2015;4(8):18-26.

6. Riskesdas. Riset Kesehatan Dasar Kementerian RI. Vol. 6, Proceedings, Annual Meeting Air Pollution Control Association. 2013.

7. Riskesdas Bali. Riskesdas Dalam Angka Provinsi Bali 2013. Vol. 239. 2013. 77 p.

8. Kemenkes. Kementerian Kesehatan Republik Indonesia. 2009.

9. Kemenkes RI. GERMAS Wujudkan Indonesia Sehat. 2016. 
Putu Susy Natha Astini, Roni Andrian Gupta, NLP. Yunianti Suntari, IDAK Surinati. Desember 2020. 13 (2). 77-86 